\title{
Hyperbasophilic immunoblasts in circulating blood in chronic inflammatory rheumatic and collagen diseases
}

\author{
F. DELBARRE, A. LE GÔ AND A. KAHAN \\ From Institut de Rhumatologie, Faculté Médecine Paris-Cochin
}

\begin{abstract}
Delbarre, F., Le Gô, A., and Kahan, A. (1975). Annals of the Rheumatic Diseases, 34, 422430. Hyperbasophilic immunoblasts in circulating blood in chronic inflammatory rheumatic and collagen diseases. The number of large circulating hyperbasophilic mononuclear cells-referred to as hyperbasophilic immunoblasts ( $\mathrm{HBI}$ - - is often increased in collagen diseases and rheumatoid arthritis (RA) and grossly reflects the degree of disease activity. In contrast, in psoriatic arthropathy the percentage of $\mathrm{HBI}$ is within the normal range. $\mathrm{HBI}$ are mainly involved in immune reactions and may provide a valuable routine test for the assessment of the latter in disease states and for the prediction of relapse in chronic collagen diseases.

Immunofluorescent techniques applied to samples from active autoimmune diseases have shown that a number of HBI are Ig-producing B-blasts. Moreover, in a few cases these intracytoplasmic immunoglobulins exhibited a rheumatoid factor-like activity, a finding which promises to yield additional information on the immunopathogenesis of RA.
\end{abstract}

In 1965 a patient was observed (by F.D.; Richard, 1975) with severe Fiessinger-Leroy-Reiter's syndrome in whom up to $5 \%$ of the circulating leucocytes were hyperbasophilic mononuclear cells of the lymphoplasmocytoid type with mitotic figures. Since then we have studied these cells in over 230 patients with various forms of rheumatic disease.

Hyperbasophilic immunoblasts (HBI) can be detected readily in smears of leucocyte concentrates, and stain well (May-Grünwald-Giemsa), with a spongy and strongly basophilic (or pyroninophilic) cytoplasm; the nucleus is usually eccentric, the nuclear-cytoplasmic ratio high, and the diameter 20-30 $\mu \mathrm{m}$ (Fig. 1). These atypical mononuclear cells, first described by Türk (1898), have been frequently seen in human blood during the course of bacterial (Gump and Fekety, 1967) or viral infections, such as infectious mononucleosis (Downey and McKinlay, 1923; Litwins and Leibowitz, 1951; Frank and Dougherty, 1953; Wood and Frenkel, 1967), although their significance was not at first realized.

In the present study circulating hyperbasophilic mononuclear cells have been estimated, using morphological criteria, in patients with a variety of rheumatic diseases. We have found an increased number of these cells in autoimmune diseases, such as rheumatoid arthritis (RA) and systemic lupus erythematosus (SLE), but not in psoriatic arthritis with acute inflammatory manifestations. These findings suggest that the occurrence of HBI cells is related more to immune reactions than to inflammation. The results of immunofluorescent techniques applied to samples from patients with active RA and SLE confirm this, leading us to the conclusion that HBI estimation may provide a simple routine test for the assessment of immune reactions in disease states and provide a guide for therapy.

\section{Material and methods}

PATIENTS

207 peripheral blood samples from 174 adults with inflammatory rheumatic diseases (Table I) were examined. Only patients with definite disease, whether acute or in remission, according to clinical and biological criteria, were included in this study. All SLE patients and some of the RA patients were receiving corticosteroid therapy. Ten patients who were treated with chlorambucil (8-10 mg daily) were studied separately. 
Table I Results of HBI test in different groups of patients

\begin{tabular}{|c|c|c|c|c|}
\hline Group studied & No. of cases & No. of samples & $\begin{array}{l}\text { HBI/ } 10^{3} \text { lympho- } \\
\text { cytes (range) } \\
(\text { mean } \pm S D)\end{array}$ & $\begin{array}{l}\% \text { of cases with } \\
\text { raised value* }\end{array}$ \\
\hline Controls & 43 & 43 & & \\
\hline Normal & 25 & 25 & $\begin{array}{l}0-5 \\
(2 \cdot 2 \pm 1 \cdot 5)\end{array}$ & \\
\hline Osteoarthrosis & 10 & 10 & $\begin{array}{l}0-4 \\
(2 \cdot 1 \pm 1 \cdot 1)\end{array}$ & $0 \cdot 0$ \\
\hline Sciatica & 8 & 8 & $\begin{array}{l}0-5 \\
(2 \cdot 5 \pm 1 \cdot 5)\end{array}$ & 0.0 \\
\hline Rheumatoid arthritis & 76 & 86 & & $57 \cdot 0$ \\
\hline Seropositive & 51 & 58 & $1-28$ & $56 \cdot 9$ \\
\hline Seronegative & 17 & 18 & $2-25$ & $66 \cdot 6$ \\
\hline SCAT(-) Latex FII+ & 8 & 10 & $1-16$ & $40 \cdot 0$ \\
\hline$S L E$ & 30 & 40 & $2-60$ & $82 \cdot 5$ \\
\hline Scleroderma & 13 & 21 & $2-10$ & $38 \cdot 1$ \\
\hline Ankylosing spondyititis & 17 & 17 & $0-4$ & 0.0 \\
\hline Psoriatic arthritis & 18 & 24 & $0-5$ & 0.0 \\
\hline Gout & 17 & 19 & $0-11$ & $31 \cdot 5$ \\
\hline Acute viral infection & 17 & 17 & $4-68$ & \\
\hline Total & 234 & 267 & & \\
\hline
\end{tabular}

* $>5 / 10^{3}$ lymphocytes.

The normal controls were 25 healthy persons from the hospital staff and eighteen patients in hospital with degenerative joint diseases. In addition, a group of seventeen children with acute viral infection (mumps 7, measles 7 , rubella 3) was included in this study. Blood samples were obtained at varying intervals from the onset of the clinical symptoms.

ASSESSMENT OF CELLS IN PERIPHERAL BLOOD Leucocyte concentrates were prepared from blood collected with EDTA- $\mathrm{Na}_{2}$, centrifuged for $15 \mathrm{~min}$ at 1500 r.p.m. in capillary tubes ( $3 \mathrm{~mm}$ internal diameter) and the buffy-coat was smeared on slides. Differential cell counts were made on May-Grünwald-Giemsa stained smears. At least 1000 and usually 2000 lymphoid cells were counted; since the identification of $\mathrm{HBI}$ presents no difficulties, differential counts done by two independent observers on different smears from the same sample always gave similar results; therefore, HBI was estimated by any one observer and the number expressed as a percentage of the total lymphocyte count. Other techniques of leucocyte or lymphocyte separation (plasma sedimentation, filtration through nylon fibres) have been tried and do not influence the results.

The criteria used to identify HBI were the intense basophilia of the cytoplasm and the leptochromatic pattern of the nucleus which showed one or two nucleoli (more clearly seen in phase microscope). They were 1.5 to 3 times the diameter of a small lymphocyte and had the nuclear-cytoplasmic ratio of large lymphocytes (Fig 1). Staining with methyl-green-pyronine indicated a high content of RNA in their cytoplasm and nucleus.

In HBI-rich samples, mitotic figures were often seen and the proliferative potential of HBI was occasionally assessed using a flash-labelling technique with ${ }^{3} \mathrm{H}$-thymidine (CEN Saclay, France) by incubating $10^{6}$ lymphocytes (for $1 \mathrm{~h}$ at $37^{\circ} \mathrm{C}$ ) in $1 \mathrm{ml}$ autologous plasma and $1 \mu \mathrm{Ci}$ isotope. Radioautography of methanol fixed smears was done by dipping the slides in Ilford $\mathrm{K} 5$ nuclear emulsion. These were developed 12 days later in Microdol-X (for $5 \mathrm{~min}$ at $20^{\circ} \mathrm{C}$ ) and stained through the emulsion with Giemsa stain. Only qualitative estimations were done, attention being focused on HBI which were found to be heavily labelled.

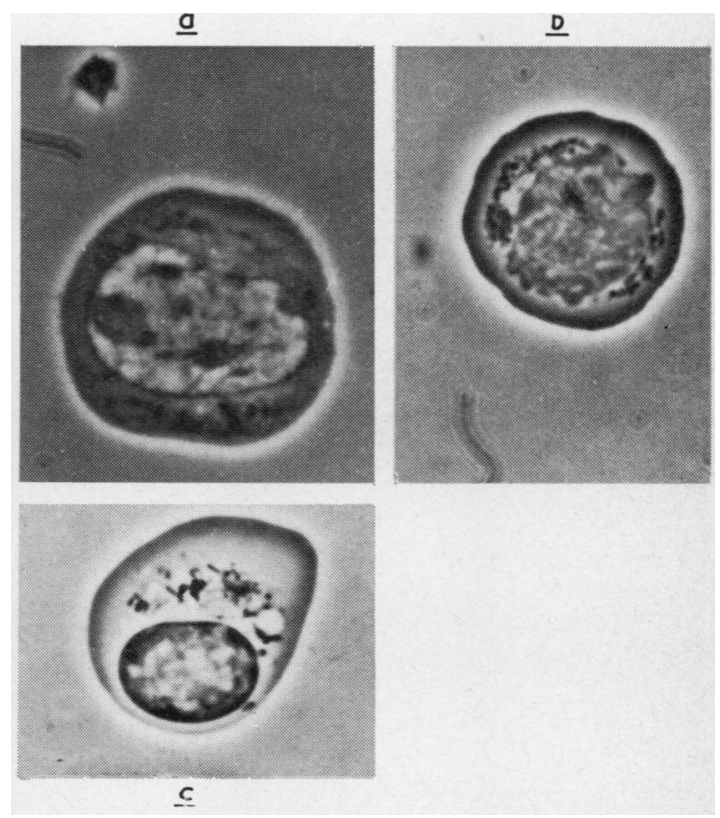

FIG. 1 Morphology of $\mathrm{HBI}$ in phase contrast microscopy $(\times 1000)$. (a) Large blast cell with prominent nucleoli. (b) Lymphocyte-like cell with dark grey cytoplasm and elongated mitochondria close to the nucleus. (c) Typical plasma cell with abundant mitochondria and well-defined archoplasm 


\section{ELECTRON MICROSCOPY}

HBI were easily identified with the electron microscope. In the least differentiated cells the cytoplasm showed many ribosomal clusters and a small amount of erga-

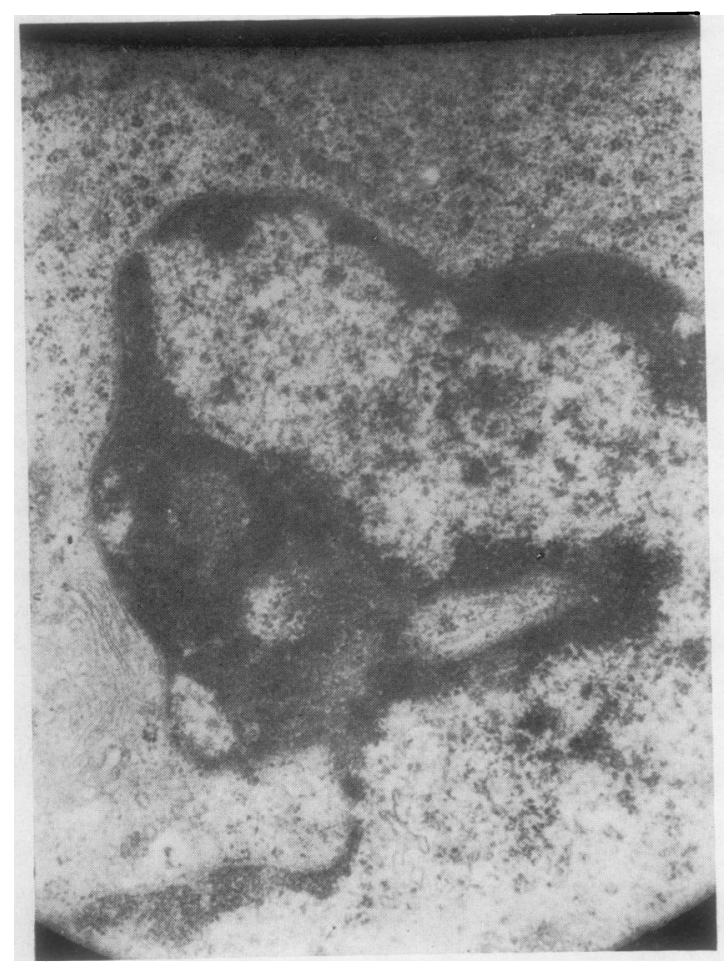

stoplasm (Fig. 2a); the nuclear chromatin was scanty or clumped. In those cells judged to be more differentiated, the ergastoplasm was well developed and showed some orientation around the nucleus (Fig. $2 b$ ).

FIG. 2 (a) Electron micrograph of HBI. Fixed: $n$ osmiumglutaraldehyde, stained with uranyl acetate and lead citrate. Large 'undifferentiated' cell. The chromatin is fine and loose; one nucleolus is present; the cytoplasm contains polyribosomal clusters and short pieces of reticulum localized in one part of the cell. $\times 7000$. (b) $\mathrm{HBI}$ with a more differentiated appearance: the ergastoplasm shows the concentric orientations seen in a classical plasma cell but the nucleus is similar to that of the undifferentiated cell. $\times 10000$

(a)

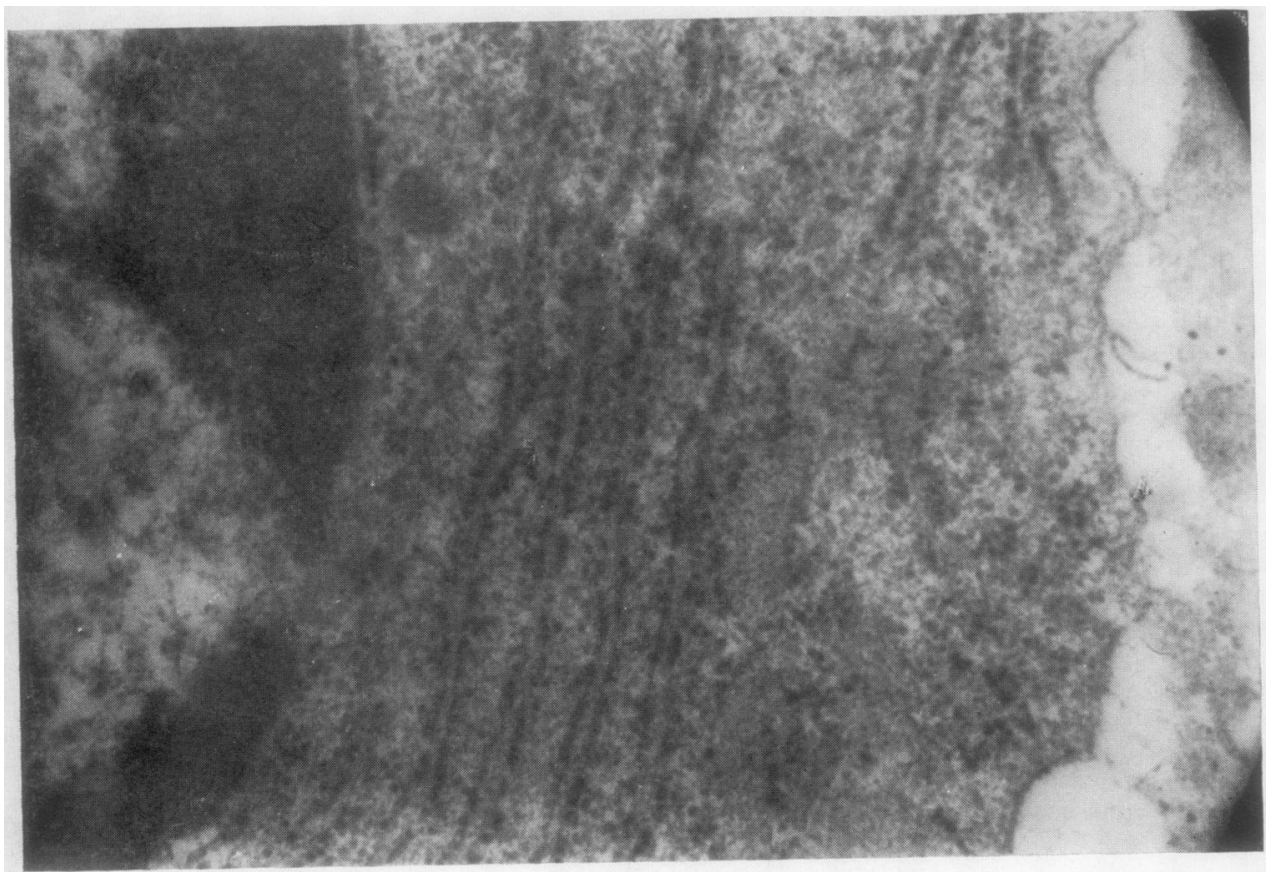


IMMUNOFLUORESCENT STAINING

Peripheral blood lymphocytes were isolated by FicollContrix density flotation, washed in Hanks's medium and cell films were prepared on a cytocentrifuge (Shandon). Acetone-fixed smears were stained using an indirect technique. They were first incubated with monospecific goat antisera (Meloy Laboratory), were thoroughly washed, and then incubated with a fluorescein-isothiocyanate conjugated rabbit antigoat-IgG antiserum (FITCRaGG, Hyland Laboratory), washed again, and mounted in buffered glycerol. The antisera or conjugates were tested by immunoelectrophoresis and the specificity of the immunofluorescent staining was ascertained on human bone marrow samples from patients with paraproteinaemia. All the reactions were performed with the same batches of antisera.

Control reactions included blocking procedures by unconjugated RaGG and incubation with FITC-RaGG alone. When the conjugated sera were used in a dilution of $1: 50$, as in the indirect technique, no specific staining was observed; however, by lowering the dilution to $1: 4$ a few cells exhibiting cytoplasmic fluorescence were found. Differential counts were made by alternate phase contrast and fluorescent microscopy for the percentage of positive cells, and at least 1000 lymphoid cells were counted.

Thirty patients (22 RA, 8 SLE) and ten normal donors were evaluated for percentage of fluorescent cells, using antihuman antisera (specific for $\alpha, \gamma, \mu, \kappa, \lambda$ ), and 17 of these were further investigated using monospecific antiIgA, anti-IgG, anti-IgM, and FITC-RaGG in a dilution of $1: 4$.

\section{Results}

The range of $\mathrm{HBI}$ concentration values in each group is given in Table I. In normal subjects the number of HBI never exceeded $5 / 10^{3}$ lymphocytes, considered to be the upper limit of normal. All values from patients with degenerative arthritis were normal. In the group with acute viral infections, the percentage of HBI was variable and depended on the day of blood sampling (Fig. 3); the highest values were observed within 3-4 days of the onset of disease, while by the 15 th day all the values were nearly normal.

Raised values (up to $60 \mathrm{HBI} / 10^{3}$ lymphocytes) were often observed in patients with RA and SLE, mainly in those with recent exacerbation of their disease; clinical improvement was usually associated with a fall in the percentage of $\mathrm{HBI}$. The relationship between HBI and disease activity is illustrated by the correlation between the HBI level and the erythrocyte sedimentation rate (ESR) in patients with RA ( $r=$ $0.2666 ; \mathrm{P}<0.02)$ and SLE $(r=0.378 ; \mathrm{P}=0.02)$ (Fig. 4). However, serial determinations of $\mathrm{HBI}$ and ESR in 8 patients did not show such a correlation, since the changes in the percentage of HBI occurred earlier than those in the ESR value. Fig. 5 gives two typical examples of dissociation between HBI and ESR. Patients with clinically inactive SLE and normal ESR often had raised values of $\mathrm{HBI}\left(>10 / 10^{3}\right.$ lymphocytes) compared with RA patients (Table II), the difference between the two groups of patients being significant.

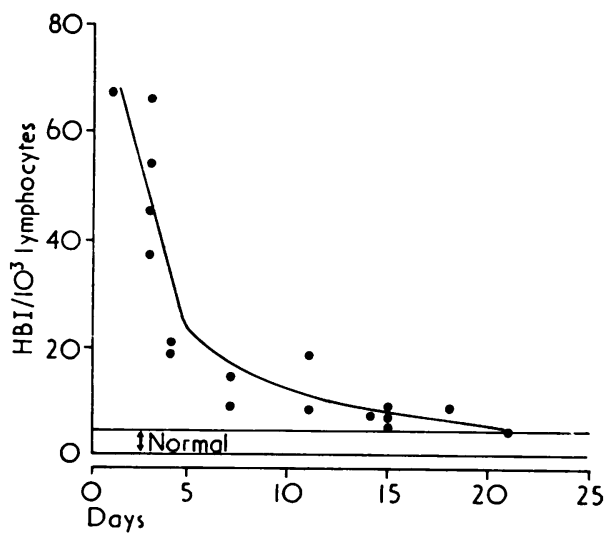

FIG. 3 Levels of $\mathrm{HBI}$ in peripheral blood during the course of viral infections. Patients with mumps, rubella, or measles were assumed to form a homogeneous group. Individual percentages of $\mathrm{HBI}$ were plotted and a schematic curve was fitted by eye

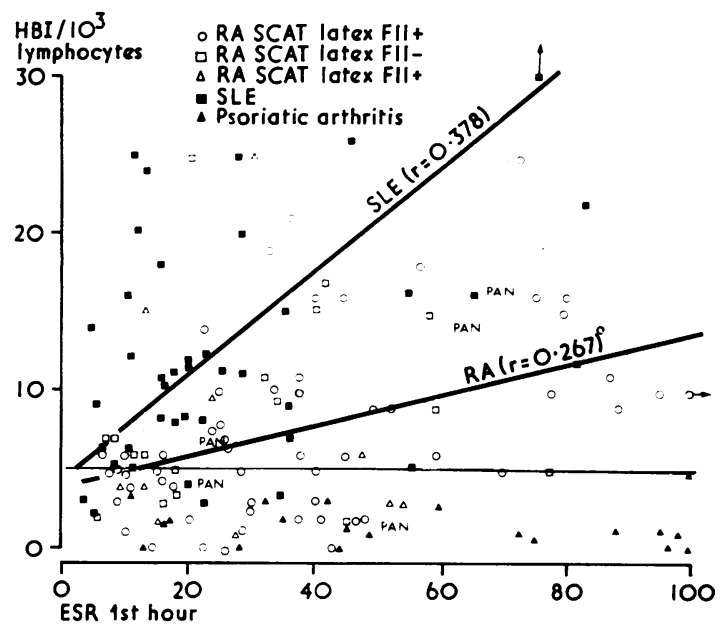

FIG. 4 Relationship between disease activity and $H B I$ shown by correlation between $H B I$ level and ESR in $R A$ and SLE patients

In SLE there was a correlation $(r=0.38 ; \mathrm{P}<0.02)$ between the percentage of HBI and gammaglobulinaemia. No other correlations were found either with total leucocyte and lymphocyte counts, with rheumatoid factor titre in RA, or with antinuclear factor titre in SLE. In 8 of 21 samples from patients with nonprogressive scleroderma there was a moderate increase of HBI.

Ten of fifteen patients with ankylosing spondylitis had clinical and laboratory evidence of active disease; all had normal HBI values. Patients with gout and moderately increased HBI all had inflammatory synovitis, while those with normal HBI values had no joint involvement. In patients with psoriatic arthritis 


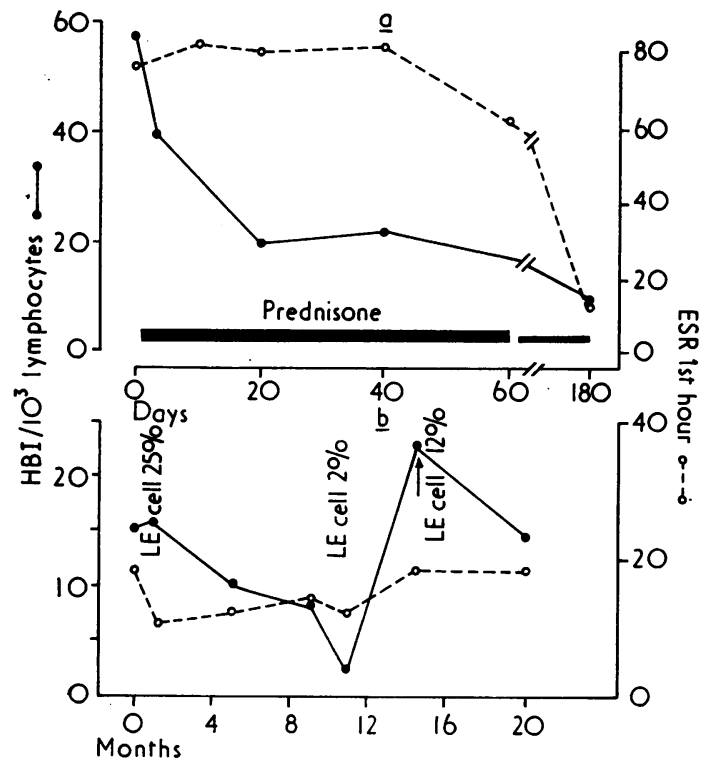

FIG. $5 \mathrm{HBI}$ level and ESR in two patients with SLE. (a) SLE in a girl hospitalized with fever, joint and pericardial symptoms, positive ANF and LE tests. In response to treatment (prednisone $40 \mathrm{mg} / \mathrm{d}$ ) the percentage of $\mathrm{HBI}$ fell rapidly but remained abnormal for several weeks, while the ESR began to decrease only one month later. (b) SLE without clinical symptoms; over a period of 20 months ESR remained normal while $A N F$ and $L E$ cells were always present; the percentage of $H B I$ was most often high. The arrow indicates a transient clinical relapse. The number of $L E$ cells and $H B I$ increased at the same time, while there was no change in the ESR value the percentage of HBI was always normal whereas ESR was raised in all but four; nine patients had a markedly raised ESR (range $60-100 \mathrm{~mm}$ ) and multiple of joint involvement.

\section{IMMUNOFLUORESCENT STAINING}

Cells which were found to fluoresce never showed the morphological features of typical plasma cells, and by alternating phase contrast and fluorescent microscopy they were identified as medium and large HBI. Few, if any, fluorescent cells were observed in the peripheral blood of normal subjects and the percentage correlated well with that of HBI (Table III). In most RA patients the percentage of fluorescent cells was increased to the same extent as that of HBI, while in SLE patients and in two RA patients fluorescent cells tended to be less numerous than HBI. There was a wide disparity in the relative number of cells positive for IgA, IgG, and IgM (Table IV), but the number of samples was too small for interpretation.

In RA patients (either seropositive or seronegative: Waaler-Rose test) and in two SLE patients, cells reacting with FITC-RaGG were found and their number did not always correlate with the total number of Ig positive cells. In a few cases, however, they probably represented all the positive cells (Table IV)

\section{EFFECT OF TREATMENT}

Corticosteroids have been found to lower the percen tage of HBI in the same way that they influence clinical improvement (Fig. 5a). This was not true for chlorambucil. In ten patients the percentage of $\mathrm{HBI}$ was estimated before treatment and again between 10

Table II Comparison of relationship between HBI and ESR in RA and SLE

\begin{tabular}{|c|c|c|c|c|c|}
\hline \multirow{3}{*}{$\underset{(\mathrm{mm})}{E S R \text { 1st h }}$} & \multirow[t]{3}{*}{ Group } & \multicolumn{4}{|c|}{ Range of $H B I$ values } \\
\hline & & \multicolumn{2}{|c|}{$5-10 / 10^{3}$ lymphocytes } & \multicolumn{2}{|c|}{$>10 / 10^{3}$ lymphocytes } \\
\hline & & No. of cases & $\%$ of cases & No. of cases & $\%$ of cases \\
\hline $0-20$ & $\begin{array}{l}\text { RA (17) } \\
\text { SLE (20) } \\
\text { Ankylosing spondylitis (75) } \\
\text { Psoriatic arthritis (4) }\end{array}$ & $\begin{array}{l}7 \\
6 \\
2 \\
0\end{array}$ & $\begin{array}{l}41 \cdot 2 \\
30 \cdot 0 \\
- \\
-\end{array}$ & $\begin{array}{r}1 \\
10 \\
0 \\
0\end{array}$ & $\begin{array}{l}5 \cdot 9^{*} \\
50 \cdot 0^{*} \\
-\end{array}$ \\
\hline $21-50$ & $\begin{array}{l}\text { RA (40) } \\
\text { SLE (15) } \\
\text { Ankylosing spondylitis (9) } \\
\text { Psoriatic arthritis (6) }\end{array}$ & $\begin{array}{r}12 \\
3 \\
0 \\
0\end{array}$ & $\begin{array}{l}30 \cdot 0 \\
20 \cdot 0 \\
- \\
-\end{array}$ & $\begin{array}{r}12 \\
9 \\
0 \\
0\end{array}$ & $\begin{array}{l}30 \cdot 0 \dagger \\
60 \cdot 0 \dagger \\
-\end{array}$ \\
\hline$>50$ & $\begin{array}{l}\text { RA (21) } \\
\text { SLE (5) } \\
\text { Ankylosing spondylitis (1) } \\
\text { Psoriatic arthritis (8) }\end{array}$ & $\begin{array}{l}7 \\
1 \\
0 \\
1\end{array}$ & $\begin{array}{l}33 \cdot 3 \\
20 \cdot 0 \\
-\end{array}$ & $\begin{array}{r}10 \\
4 \\
0 \\
0\end{array}$ & $\begin{array}{l}47 \cdot 6 \\
80 \cdot 0 \\
- \\
-\end{array}$ \\
\hline
\end{tabular}

$* \mathbf{P}<0.01$ (exact probability calculated according to the principles for small series). $+\mathbf{P}<0.05$ ( $x^{2}$ test).

Number of cases in each group in parentheses. 
Table III Comparison between morphology and immunofluorescent (IF) staining

\begin{tabular}{|c|c|c|c|c|c|}
\hline \multirow[t]{2}{*}{ Group } & \multirow[t]{2}{*}{ No. of cases } & \multicolumn{2}{|c|}{ HBI/103 lymphocytes } & \multirow[t]{2}{*}{ Correlation } & \multirow[t]{2}{*}{$P$} \\
\hline & & Giemsa staining & IF staining & & \\
\hline $\begin{array}{l}\text { Controls } \\
\text { RA }\end{array}$ & 10 & $2 \cdot 4 \pm 1.9$ & $2 \cdot 0 \pm 1 \cdot 6$ & 0.81 & $<0.01$ \\
\hline $\begin{array}{l}\text { Seropositive } \\
\text { Seronegative } \\
\text { SLE }\end{array}$ & $\begin{array}{c}12^{*} \\
8 \\
8\end{array}$ & $\begin{array}{l}11 \cdot 9 \pm 7 \cdot 7 \\
13 \cdot 4 \pm 9 \cdot 4 \\
33 \cdot 8 \pm 32\end{array}$ & $\begin{array}{l}10 \cdot 6 \pm 6 \cdot 5 \\
11 \cdot 3 \pm 10 \cdot 6 \\
16 \cdot 1 \pm 12 \cdot 9\end{array}$ & $\begin{array}{l}0.93 \\
0.84 \\
0.59\end{array}$ & $\begin{array}{l}<0.01 \\
<0.01 \\
\text { NS }\end{array}$ \\
\hline
\end{tabular}

* Two cases with high HBI value $(33,34)$ and low percentage of fluorescent cells $(6,8)$ are not included in the group.

Table IV Results of immunofluorescent staining with monospecific antisera in 10 cases of RA and 7 cases of SLE

\begin{tabular}{|c|c|c|c|c|c|c|c|c|}
\hline \multirow[t]{3}{*}{ Case no. } & \multirow[t]{3}{*}{ Diagnosis } & \multirow{3}{*}{$\begin{array}{l}\text { Waaler-Rose } \\
\text { test }\end{array}$} & \multicolumn{6}{|c|}{$\mathrm{HBI} / 10^{3}$ lymphocytes } \\
\hline & & & \multirow{2}{*}{$\begin{array}{l}\text { Giemsa } \\
\text { staining }\end{array}$} & \multicolumn{5}{|c|}{ Immunofluorescent staining with } \\
\hline & & & & $\overline{a-\operatorname{Ig} A}$ & $a-\operatorname{Ig} G$ & $a-\operatorname{Ig} M$ & $a-\operatorname{Ig*}$ & $R a G G \dagger$ \\
\hline 1 & RA & + & 9 & 0 & 3 & 7 & ND & 0 \\
\hline 2 & RA & + & 6 & 1 & 3 & 2 & 4 & 5 \\
\hline 3 & RA & + & 13 & 3 & 2 & 5 & 6 & 2 \\
\hline 4 & RA & + & 33 & 2 & 2 & 1 & 6 & 6 \\
\hline 5 & RA & + & 34 & 1 & 2 & 3 & 8 & 7 \\
\hline 6 & RA & - & 31 & 6 & 8 & 3 & 20 & 15 \\
\hline 7 & RA & - & 11 & 0 & 1 & 3 & 3 & 2 \\
\hline 8 & RA & - & 11 & 2 & 1 & 5 & 6 & $\overline{1}$ \\
\hline 9 & RA & - & 8 & 0 & 1 & 0 & 1 & 1 \\
\hline 10 & RA & - & 7 & 1 & 1 & 3 & 7 & 4 \\
\hline 11 & SLE & + & 24 & 5 & 19 & 4 & 25 & 4 \\
\hline 12 & SLE & - & 25 & 0 & 4 & 3 & 6 & 0 \\
\hline 13 & SLE & - & 15 & 0 & 2 & 2 & 5 & 0 \\
\hline 14 & SLE & - & 44 & 4 & 11 & 12 & 24 & 0 \\
\hline 15 & SLE & + & 104 & 1 & 14 & 7 & 15 & 0 \\
\hline 16 & SLE & - & 10 & 3 & 0 & 1 & 3 & 0 \\
\hline 17 & SLE & - & 45 & 13 & 14 & 7 & ND & 7 \\
\hline
\end{tabular}

* Specific for the 3 heavy and the 2 light chains.

+ Conjugated rabbit antigoat IgG (dilution 1:4) alone.

$\mathrm{ND}=$ not done.

and 60 days after treatment was started: no change was observed except an apparent increase of HBI level in a few cases, probably due to lymphopenia since the number of $\mathrm{HBI} / \mathrm{mm}^{3}$ remained the same.

In the patient suffering from Reiter's syndrome (the original case), treatment by antilymphocytic serum produced a marked increase in the HBI level $(>50 / 1000)$. Three patients with multiple sclerosis were also treated with (horse) antilymphocyte globulin alone. The percentage of HBI markedly increased, reaching a peak value of $50 / 10^{3}$ lymphocytes at day 7 and returning to the initial level within a few days.

\section{Discussion}

The present study shows that the ratio of hyperbasophilic mononuclear cells to lymphocytes is low, with closely grouped values occurring in normal subjects. This agrees with the findings of other investigators
(Bond, Fliedner, Cronkite, Rubini, Brecher, and Schork, 1959; Crowther, Fairley, and Sewel, 1969a; Amiel and Schneider, 1971). The percentage of HBI is often increased in pathological situations where inflammatory and immune reactions occur together, such as acute viral infections and connective tissue diseases. In acute viral infections this increase is transient, going on for 10-15 days, while in connective tissue diseases, particularly in SLE, the HBI level may be high for long periods and grossly reflect the degree of clinical activity. Inflammation alone does not sufficiently explain these results, since patients suffering from psoriatic arthritis, even if associated with acute polyarthritis, have normal HBI values.

Another situation which may involve atypical mononuclear cells in peripheral blood is antigenic stimulation (Rechtchikov and Matsukura, 1962; Cannon and Wissler, 1965; Crowther, Fairley and Sewel, 1969b; Lalla, Vesikari, and Virolainen, 1973). 
Hence, the vigorous HBI response to antilymphocyte globulin therapy may be interpreted as an immune reaction against the horse globulin, despite the lack of direct immunological proof. The observations of Denman and Frenkel (1968) in the rat, and those of Traeger, Revillard, Brochier, Touraine, and Berthoux (1970) in man, agree with this hypothesis. A number of these cells morphologically resemble the large, rapidly dividing hyperbasophilic blasts which are released into the efferent lymph and the thoracic duct by antigenically stimulated lymph nodes (Hall and Morris, 1963; Hall and Morris, 1965; Hall, Morris, Moreno, and Bessis, 1967; Delorme, Hodgett, Hall, and Alexander, 1969; Sprent and Miller, 1971). In addition to the morphological criteria, as has been noted for the lymph-borne immunoblasts (Cunningham, Smith, and Mercer, 1966; Hummler, Harris, Tomasini, Hechtel, and Farber, 1966; Mandel and Asofsky, 1968; Hall, 1970; Hall, Parry, and Smith, 1971), blood hyperbasophilic mononuclear cells are capable of producing immunoglobulins (Hullinger and Sorkin, 1963; van Furth, Schmit, and Hijmans, 1966; Hummler and others, 1966; van Furth, 1969). They may therefore be considered as activated Blymphocytes undergoing differentiation into plasma cells (Gowans and Knight, 1964; Birbeck and Hall, 1967; Hall and others, 1971). There is some evidence from experimental data that T-blasts too may circulate and differentiate into effector cells of cellular immunity (Hall and others, 1967; Denham, Hall, Wolf, and Alexander, 1969; Sprent and Miller, 1971) and possibly into memory cells (Sprent and Miller, 1972).

The development of radioautography has shown that these cells have a proliferative potential, since they synthesize DNA as they circulate in the blood (Bond and others, 1959; Carter, 1965; Epstein and Brecher, 1965). They were found to be a heterogeneous group both morphologically and by labelling with ${ }^{3} \mathrm{H}$-thymidine (Bond and others, 1959; Wood and Frenkel, 1967), which increases in number under certain conditions of haemopoietic stress (Bond, Fliedner, and Andrews, 1961; Harris, Haigh, and Kugler, 1963; Harris and Kugler, 1971) and may include multipotent stem cells (Barnes and Loutit, 1967). From these findings it is assumed that the occurrence of hyperbasophilic mononuclear cells in the peripheral blood is related more to immune reactions than to inflammation and this hypothesis is supported by the work of others (Crowther and others, 1969b; Lalla and others, 1973). Consistent with this possibility are the following observations. (1) Cells with the ultrastructure of the lymph-borne immunoblasts seen in experimental conditions (Hummler and others, 1966; Hall and others, 1967) are found in HBI-rich buffy coat. (2) The increase of HBI is generally accompanied by a corresponding increase of immunoglobulin-producing cells, prob- ably the most differentiated cells observed by electron microscopy. As has been noted in experimental immunization (Hullinger and Sorkin, 1963; Kearney and Halliday, 1965; Hummler and others, 1966), there is some evidence that in connective tissue diseases B-blasts differentiating into immunoglobulin-secreting cells may circulate in response to some unknown stimulus.

However, the discrepancy between the cytological and immunofluorescent techniques in some cases of SLE and RA raises the question of whether all hyperbasophilic cells are immunoblasts or not. Since the morphological criteria are debatable and since the blood leucocytes form a heterogeneous cell population, other hypotheses should be considered. One possibility is that the hyperbasophilic cells are bonemarrow derived multipotent stem cells (Barnes and Loutit, 1967), but no data are available (e.g. from bioassays). Another possibility is that they are macrophage precursors liberated from the bone marrow in response to tissue injury. Horwitz and co-workers, studying the proliferative potential of blood mononuclear cells, have shown that macrophages may derive from nonphagocytic 'lymphocytelike cells' (Horwitz, Stastny, and Ziff, 1970; Horwitz and Steagall, 1972): these DNA synthesizing macros phage precursors are found in large numbers in SLE and RA patients, and they have the morphologicat features of 'atypical lymphocytes' according to the criteria of Wood and Frenkel (1967). These results conflict with our results, though there is no direct evidence that the cell we call $\mathrm{HBI}$ and the macrophage precursor are identical. Obviously, in morphological terms the HBI are but a subgroup of the proliferating atypical lymphocyte population (Bond and others, 1959; Wood and Frenkel, 1967; personal observations). Furthermore not all DNA-synthesizing cells differentiate into macrophages (Horwitz and Steagall, 1972). The moderate increase of hyperbasophilic cells in gout arthropathy, which could be accounted for by the macrophage precursor hypothesis, is no argument against the concept that these cells are immunoblasts, since immune reactions (probably in response to tissue injury) have already been proposed in gout (Howell, Chamberlain, Perry, Torrigliani, and Roitt, 1972). Moreover, absence of cytoplasmic immunoglobulin is not incompatible with immuno- $\sim$ logical function; nonfluorescent HBI may be either $N$ immature B-blasts (a hypothesis consistent with some N ultrastructural features) or T-blasts, the function of $\omega$ which is not antibody secretion but perhaps delayed hypersensitivity-type reactions. Circulating T-blasts $\stackrel{\mathcal{C}}{\subset}$ have been shown in mice (Sprent and Miller, 1971) and in patients with infectious mononucleosis (Sheldon, Papamichail, Hemsted, and Holborow, 1973). Further investigations are needed to confirm this possibility in connective tissue disease. The immunological significance of HBI circulation remains to be deter- 
mined, but it is likely from experimental data that it may play a role in the immunopathogenesis of connective tissue disease. In animals, circulating immunoblasts have been shown to migrate into inflammatory exudates (McGregor, Koster, and Mackress, 1971; Asherson and Allwood, 1972), to enter homografts (Hall and others, 1967), and to destroy allogeneic cells in vitro (Denham and others, 1969). Hall and colleagues have clearly shown that lymph-borne immunoblasts are endowed with a 'messenger function' in the propagation and amplification of the immune response (Hall, 1967, 1969). It is therefore interesting to find cells reacting with rabbit IgG in patients with RA, although further investigations are needed to confirm that they are rheumatoid factor-secreting cells. These preliminary data will be compared with those of Vaughan,
Tanimoto, Chihara, and Johnson (1974), who found plaque-forming cells reacting with rabbit haemolysinsensitized erythrocytes in the peripheral blood of patients with RA. These observations indicate that HBI circulation is a factor in the pathogenesis of RA and presumably of other autoimmune disorders.

From a practical viewpoint the presence of increased numbers of hyperbasophilic mononuclear cells in the peripheral blood indicates underlying immune reactions, and may also allow rapid and simple prediction of relapse in patients with chronic autoimmune disorders. Since the HBI level is normal in psoriatic arthritis, it may be used as a negative criterion for diagnostic purposes.

The authors thank Mrs. E. Tournant and M. Kharouby for excellent technical assistance.

\section{References}

Amiel, J. L., AND SchNeider, M. (1971) Bull. Cancer, 58, 9 (Etudes immunologiques dans la maladie de Hodgkin)

AsHerson, G. L., AND ALLwOOD, G. G. (1972) Immunology, 22, 493 (Inflammatory lymphoid cells: cells in immunized lymph node that move to sites of inflammation)

BARNES, D. W. H., AND LouTit, J. F. (1967) Lancet, 1, 1138 (Haemopoietic stem cells in peripheral blood)

BirbeCK, M. S. C., AND HALL, J. G. (1967) Nature, 214, 183 (Transformation in vivo of basophilic lymph cells into plasma cells)

Bond, V. P., Fliedner, T. M., ANd Andrews, G. (1961) J. Lab. clin. Med., 57, 711 (Deoxyribonucleic acid synthesizing cells in the blood of man and dog exposed to total body irradiation)

- - C Cronkite, E. P., Rubini, J. R., Brecher, G., ANd Schork, P. K. (1959) Acta Haemat., 21, 1 (Proliferative potentials of bone marrow and blood cells studied by in vitro uptake of ${ }^{3} \mathrm{H}$-thymidine)

Cannon, D. C., AND Wissler, R. W. (1965) Nature, 207, 654 (Migration of spleen cells into the blood stream following antigenic stimulation of the rat)

CARTER, R. L. (1965) Blood, 26, 579 (The mitotic activity of circulating atypical mononuclear cells in infectious mononucleosis)

Crowther, D., Fairley, G. H., ANd Sewel, R. L. (1969a) Brit. med. J., 2, 473 (Significance of the changes in the circulating lymphoid cells in Hodgkin's disease) man)

Cunningham, A. J., Smith, J. B., ANd Mercer, E. H. (1966) J. exp. Med., 124, 701 (Antibody formation by single cells from lymph nodes efferent lymph of sheep)

Delorme, E. J., Hodgett, J., Hall, J. G., And AleXander, P. (1969) Proc. roy. Soc. B, 174, 229 (The cellular immune response to primary sarcomata in rats. I. The significance of large basophilic cells in the thoracic duct lymph following antigenic challenge)

Denham, S., Hall, J. G., Wolf, A., AND Alexander, P. (1969) Transplantation, 7, 194 (The nature of cytotoxic cells in lymph following primary antigenic challenge)

Denman, A. M., AND Frenkel, E. P. (1968) Immunology, 14, 115 (Mode of action of antilymphocyte globulin. II. Changes in the lymphoid cell population in rats treated with antilymphocyte globulin)

Downey, H., AND MCKINLAY, C. A. (1923) Arch. intern. Med., 32, 82 (Acute lymphadenosis compared with acute lymphatic leukemia)

EPSTEIN, L. B., AND BRECHER, G. (1965) Blood, 25, 197 (DNA and RNA synthesis of circulating atypical lymphocytes in infectious mononucleosis)

Frank, F. A., AND DougherTy, T. F. (1953) J. Lab. clin. Med., 42, 538 (The assessment of stress in human subjects by means of quantitative and qualitative changes of blood lymphocytes)

FURTH, R. VAN (1969) Semin. Haemat., 6, 84 (The formation of immunoglobulins by circulating lymphocytes)

- Schuit, H. R. E., AND Hijmans, W. (1966) Immunology, 11, 29 (The formation of immunoglobulins by human tissues in vitro. IV. Circulating lymphocytes in normal and pathological conditions)

Gowans, J. L., AND KNIGHT, E. J. (1964) Proc. roy. Soc. B, 159, 257 (The route of recirculation of lymphocytes in the rat)

Gump, D. W., AND FeKETY, F. R. (1967) J. Lab. clin. Med., 69, 428 (The relationship of infection and DNA synthesizing cells in human blood)

HaLl, J. G. (1967) J. exp. Med., 125, 737 (Studies of the cells in the afferent and efferent lymph of lymph nodes draining the site of skin homografts) 
(1969) Lancet, 1, 25 (Effector mechanisms in immunity)

(1970) Rev. eur. Etud. clin. biol., 15, 783 (Demonstration of antibody on lymph borne immunoblasts by bacterial adherence)

AND Morris, B. (1963) Quart. J. exp. Physiol., 48, 235 (The lymph borne cells of the immune response)

- - _ (1965) J. exp. Med., 121, 901 (The origin of the cells in the efferent lymph from a single lymph node)

- - - Moreno, G. D., AND Bessis, M. C. (1967) Ibid., 125, 91 (The ultrastructure and function of the cells in lymph following antigenic stimulation)

—-, PARry, D., AND SmITH, M. E. (1971) Immunology, 20, 625 (Antibody production by lymph borne immunoblasts following subcutaneous injection into xenogeneic recipients)

Harris, P. F., AND Kugler, J. H. (1971) J. Anat., 108. 1 (Unusual mononuclear cells in guinea-pig peripheral blood during anaemia)

--, HaIGH, G., AND KUGler, J. H. (1963) British J. Haemat., 9, 385 (Quantitative studies of mitosis and DNA synthesizing cells in bone marrow and blood of guinea-pig recovering from sublethal whole body gamma irradiation)

Horwitz, D. A., and Steagall, R. V. (1972) J. clin. Invest., 51, 760 (The development of macrophages from large mononuclear cells in the blood of patients with inflammatory disease)

- Stastny, P., AND ZifF, M. (1970) J. Lab. clin. Med., 3, 391 (Circulating deoxyribonucleic acid synthesizing mononuclear leukocytes. Increased numbers of proliferating mononuclear leukocytes in inflammatory disease)

Howell, F. A., Chamberlain, M. A., Perry, R. A., Torrigiani, O., and Roitt, I. M. (1972) Ann. rheum. Dis., 31, 129 (IgG antiglobulin levels in patients with psoriatic arthropathy, ankylosing spondylitis and gout)

Hullinger, L., AND Sorkin, E. (1963) Nature, 198, 299 (Synthesis of antibodies by blood leucocytes of the rabbit)

Hummler, K., Harris, T. N., Tomasini, N., Hechtel, M., and Farber, M. B. (1966) J. exp. Med., 124, 255 (Electron microscopic observation on antibody producing cells in lymph and blood)

Kearney, R., and Halliday, W. J. (1965) J. Immunol., 95, 109 (Enumeration of antibody forming cells in the peripheral blood of immunized rabbits)

Lalla, M., Vesikari, T., AND Virolainen, M. (1973) Clin. exp. Immunol., 15, 193 (Lymphoblast proliferation and humoral antibody response after rubella vaccination)

Litwins, J., AND Leibowitz, S. (1951) Acta Haemat., 5, 223 (Abnormal lymphocytes (virocytes) in viral diseases other than infectious mononucleosis)

MCGregor, D. D., Koster, F. T., AND MACKNeSs, G. B. (1971) J. exp. Med., 133, 389 (The mediator of cellular immunity. I. The life span and circulation dynamics of the immunologically committed lymphocyte)

MANDEL, M. A., AND AsOFSKy, R. (1968) J. Immunol., 100, 363 (Studies of thoracic duct lymph cells in mice)

Rechtchikov, V. P., AND Matsukura, M. (1962) Rev. franc. Étud. clin. biol., 7, 760 (Les cellules hyperbasophiles dans le sang peripherique aprés greffe de peau allogénique chez le lapin)

RichaRD, C. (1975) Le test des immunoblastes pour le diagnostic des maladies rhumatismales. Thesis. University of Paris V

Sheldon, P. J., Papamichail, M., Hemsted, E. H., and Holborow, E. J. (1973) Lancet, 1, 1153 (Thymic origin of atypical lymphoid cells in infectious mononucleosis)

Sprent, J., AND Miller, J. A. P. (1971) Nature (New Biol.), 234, 195 (Activation of thymus cells by histocompatibility antigens)

__ _ - (1972) Cell. Immunol., 3, 385 (Interaction of thymus lymphocytes with histocompatible cells. II. Recirculating lymphocytes derived from antigen-activated thymus cells)

Traeger, J., Revillard, J. P., Brochier, J., Touraine, J. L., and Berthoux, F. (1970) 'Immunosuppressive activity of anti-lymphocyte serum in humans' in 'Proceedings of the VII Int. Congress of Allergy', p. 446. Excerpta Medica, Amsterdam

TüRK,W. (1898) (Editor) In 'Klinische Untersuchungen über das verhalten des Blutes bei akuten Infektions Krankheiten'. Braumüller, Vienna

Vaughan, J. H., Tanimoto, K., Chihara, T., and Johnson, J. S. (1974) Int. Symposium on Immunological aspects of Rheumatoid Arthritis, Montpellier, France, March 28 (Rôle of rheumatoid factors in the pathogenesis of rheumatoid arthritis)

Wood, T. A., ANd Frenkel, E. P. (1967) Amer. J. Med., 42, 923 (The atypical lymphocyte) 